\title{
2016 年度日本神経学会北海道地区生涯教育講演会抄録
}

\author{
日 時： 2017 年 3 月 5 日（日） \\ 会 場 : 北海道大学医学部学友会館フラテホール
}

認知症とともに暮らせる社会に向けて一Rights Based Approach について一

$$
\text { 粟田 主一（東京都健康長寿医療センター） }
$$

わが国の認知症関連施策は 1963 年の老人福祉法にはじ まる. 2000 年の介護保険制度によって, すべての区市町村 が保険者となり，40 歳以上のすべての国民が被保険者とな った．被保険者は要介護認定を受けるとその限度額内で 10\%の自己負担でサービスを利用することができる、これ によって多様なサービスが創出され, サービス利用のアク セシビリティも向上した. しかし，2003 年の高齢者介護研 究会では, 認知症高齢者の家族の介護負担が軽減していな いこと, 認知症に対する理解が不足していること, かかり つけ医の診断力に問題があることなどが指摘されている. これを受けて, 2004 年に認知症に対する偏見克服を目的に 「痴呆」から「認知症」への呼称変更が行われ，2005年に 認知症サポーター養成講座, 同年より認知症サポート医養 成事業, 2006 年よりかかりつけ医認知症詨応力向上研修事 業がはじまり, 地域包括支援センターが設置され, 2008 年 に認知症疾患医療センターが設置された。こうして, 医療 サービス，地域包括支援センター，介護保険サービスによ る保健・医療・介護の連携体制が構築されるようになった. しかし，それでも，現実にはサービス間の断絶は深刻であ
り，診断にアクセスできない認知症高齢者は多い. 2012 年 に公表されたオレンジプランの基本理念は地域包括ケアシ ステムの実現であり, その戦略として認知症ケアパスの作 成と認知症初期集中支援チームの設置がすべての市町村に 求められた。 これよって, ステージに応じた統合ケア提供 体制の構築が市町村の責務とされ, 都道府県にはそのため の人材育成が求められるようになった. 2015 年に公表され た新オレンジプランの重要なコンセプトは「認知症の人や その家族の視点の重視」である.このことに重大な影響を 及ぼしたのは 2014 年に発足した「日本認知症ワーキング グループ」であり，共同代表は「認知症になってからも希 望と尊厳をもって暮らすことができる社会をめざして活動 する」と宣言し, 認知症の診断後支援が不足する現状を訴 えた. 本人が主体として政策や地域づくりに参加するあり 方は，世界保健機関や国際認知症同盟が推奨する権利に基 づくアプローチ（Rights Based Approach）に一致する. 認知症の有無に関わらず, 障害の有無に関わらず, 人々の 権利が尊重され, 希望と尊㛜をもって暮らせる社会を実現 すること.それが今日の私たちが向かうべき方向であろう. 
中枢神経系炎症性脱髄疾患の今と昔

\section{松井 真 (金沢医大·医・神経内科学)}

多発性硬化症（multiple sclerosis : MS）は中枢神経系の炎症 性脱髄疾患に分類されるが、この他、視神経春髄炎 (neuromyelitis optica：NMO)、バロー同心円硬化症、急性 散在性脳春䯣炎、急性横断性春髄炎、中枢末梢連合脱髄症、 特発性視神経炎などがこの範疇に入る。このうち、MS と NMO は分子レベルでの病態解明が進んでいるが、実臨床で は20 年前と変わらない疾病理解の下で、現代医学の進歩に 基づいた医療が行われていない事実がある。しかし、昔も 今も変わらないのは急性期治療であり、MS・NMO ともに ステロイドパルス療法が主役である。本治療法は、疾患に 関与するあらゆる免疫学的因子や炎症性物質を抑制するこ とで、進行中の組織破壊に向から炎症反応を終息させるこ とを目的とした、いわば火事場の放水のような位置づけに ある。パルス療法への反応が不十分な場合、補体や自己抗 体除去に有効な血漿浄化療法を行うと奏功する症例があ る。これは、中枢神経の脱髄や組織傷害の現場では炎症細 胞浸潤が共通の所見であっても、一部の MS 患者と特に NMO 患者では、液性免疫が病態に関与していることを示唆 する。MS に関連した自己抗体は不明であるが、NMO では
抗アクアポリン 4（AQP4）抗体の病因的役割が明らかにさ れている。したがって、NMO の再発抑制には、副腎皮質ス テロイド薬や免疫抑制薬が用いられる。一方、MS の病態 は細胞性免疫異常に起因し、炎症惹起性サイトカインを産 生する Th1 細胞と Th17 細胞により引き起こされる。IL-4 などを産生する Th2 細胞は対抗因子として重要である。 IFN- $\beta$ やグラチラマー酢酸塩注射製剂は免疫応答を Th 2 側 に偏倚させることで MS の再発予防効果を発揮する。フィ ンゴリモドやナタリズマブは、炎症細胞が中枢神経組織に 侵入することを間接的または直接的に抑制することで高い 有効性を示すが、進行性多巣性白質脳症のリスクがあり MS の第二選択薬である。MS では、臨床的再発がない場合 でも、組織内では脱髄・炎症が生じていることが MRI で検 知でき、また不可逆的な病変が蓄積するので、 2010McDonald 改訂診断基準を用いて早期に診断し、早期に 再発予防治療を開始することが、QOL の夕ならず生命予後 の改善にも繋がる。

\section{神経筋電気診断}

\section{園生 雅弘（帝京大神経内科）}

神経筋電気診断は、それ単独で診断が下せるものではなく、 必ず神経症候二病歴と神経所見の検討が出発点となる。症候 学拔きの電気診断はあり得ない。症候から概ね局在診断、病 名㟝断の見当をつけて、残りの未解決点を電気生理で解決す るのが正しいやり方である。病歴と診察を踈かにして、画像 のみに頼ると多くの誤診を招く。そのような実例を呈示する。 症候学を柾かにして、画像や遗伝子などの検査のみに頼るよ うでは、神経専門医の資格はない。

MRI などの画像診断は有用な検査であることは間違いない が、特異度に問題がある。即ち、手のしびれがある患者で頸 椎 MRIに異常が見られたからと言って、しびれの原因は頸椎 症とは言えない。これに対し、電気診断は患者の症候と直接 対応させることができるのが利点となる。即ち、筋力低下や 感覚脱失・高度低下の原因がどこかの病変局在を直接診断で きる可能性がある。「筋電図は八ンマーの延長」と言われる所 以である。

神経筋電気診断の前提となる症候学において、皮節や筋節の 知識は重要である。このうち特に筋節においては、成書間の 差があることが問題となる。演者は症例での経験に基づく筋 節表を公表して来ているので参照していただきたい。固有手 筋については、正中神経支配の短母指外転筋が主に T1 支配、
背側骨間筋・小指外転筋などの尺骨神経支配固有手筋が主に C8 支配という説が、Levin らによって唱えられた。演者ら はこの正中-T1、尺骨-C8 という関係が、むしろ前腕屈筋に おいて明確に成り立つことを示した。

下肢においては下垂足の鑑別が重要な電気診断のテーマとな る。下垂足の代表的な原因疾患としては、腓骨神経麻瘏と L5 神経根症が挙げられる。両者の鑑別において重要なのは、L5 筋節だが腓骨神経支配ではない筋であり、これには、脛骨神 経支配の下腿筋である後脛骨筋、長趾屈筋、長母趾屈筋、 hamstrings 中の脛骨神経支配の半腱様筋、半膜様筋、上殿神 経支配の中殿筋、大腿筋膜張筋などがある。これらの筋の障 害の有無を臨床的・針筋電図的に検討することが重要となる。 最後に筋萎縮性側索硬化症（ALS） と頸椎症、特に頸椎症性 筋萎縮症 (CSA) の鑑別も重要な電気診断のテーマとなる。 $\mathrm{ALS}$ では、上肢でも $\mathrm{C} 5$ から $\mathrm{T} 1$ まで広汎な筋力低下を呈す ること、上下肢広汎な線維束自発電位 (FPs)を呈すること、 僧帽筋で反復神経刺激試験での漸減現象や針筋電図での脱神 経や FPs を認めることが診断の手がかりとなる。一方 CSA では、筋力低下が正確に髄節性（segmental）に限局するこ と、FPs はあっても少量であることなどが特徴となる。 


\section{診断と治療につながる神経病理}

吉田 眞理（愛知医大加齢医科学研）

診断と治療につながる中枢病理診断は 2 つに大別され る。ひとつは脳生検に代表される診断で、緊急性があり組 織診断が治療法の決定に直結する。第二は慢性、進行性の 変性疾患の臨床診断にフィードバックする剖検を中心とす る病理診断である。

脳生検が必要となる病巣は、CT・MRI の画像診断上の 空間占拠性病変で、特に悪性腫瘍の治療導入には不可欠で ある。原発性・転移性脸腫晹、悪性リンパ腫、血管内悪性 リンパ腫、細菌、ウィルス、真菌など種々の感染症に伴う 脳膿瘍などの空間占拠性病変、脱䯣疾患による腫瘍様空間 占拠性病変が問題となることが多い。肥厚性硬膜炎、脳肉 芽腫性血管炎などの血管炎も対象となる。紋生検は正確な 診断にたどりつけば価值が高いが、侵襲的検查であり、病 期や治療による病理像の修飾、採取組織が小さく、病巣の 的確な採取に至らないサンプリングエラーが生じることも あり、診断に難橴することは少なくない。生検前に鑑別疾 患と病巣の選択に関する議論を、臨床医、神経放射線科医、 脳外科医、病理医間で行っておくことが円滑な診断に結び つく。鑑別診断上問題となる頻度の高い疾患は、悪性リン
パ腫、血管内悪性リンパ腫、グリオーマ、多発性硬化症・ 視神経性脊䯣炎含む脱䯣疾患、進行性多巣性白質脳症 (progressive multifocal leukoencephalopathy、PML) な どであり、特に白質病変の鑑別として脱檤疾患と腫瘍性病 変、PML が重要となる。脳生検は可能な限りステロイドな どの治療前に行うことが原則である。また神経核内封入体 病では皮膚生検が補助診断として有用である。

一方、神経変性疾患では神経病理学的知識が臨床診断の 助けとなる。アルツハイマー病、パーキンソン病、レビー 小体型認知症、多系統萎縮症、進行性核上性麻痺、大脳皮 質基底核変性症、筋萎縮性側索硬化症、前頭側頭葉変性症 などの神経変性疾患は、神経細胞やグリア細胞内に形成さ れる封入体の形態とその構成蛋白から病理診断され、各疾 患の解剖学的構造に沿った病理学的進展様式が提唱されて いる。核医学検查法の進歩により、生前にアミロイド $\beta$ 蛋 白やタウ蛋白の脳内の沈着、ドパミン神経細胞の動態の可 視化が可能となっている。臨床、画像と連結した的確な病 理診断の蓄積は治療法開発へ不可欠な道程である。 